\title{
Current Status of Camel Dairy Processing and Technologies: A Review
}

\author{
Alemnesh Yirda ${ }^{1}$, Mitiku Eshetu $^{2 *}$, Kibebew Babege ${ }^{3}$ \\ ${ }^{1}$ Department of Animal Sciences, Selale University, Fitche, Ethiopia \\ ${ }^{2}$ School of Animal and Range Sciences, Haramaya University, Dire Dawa, Ethiopia \\ ${ }^{3}$ Department of Animal Production and Technology, Kebri Dehar University, Kebri Dehar, Ethiopia \\ Email: *mitikuguya@yahoo.com
}

How to cite this paper: Yirda, A., Eshetu, M. and Babege, K. (2020) Current Status of Camel Dairy Processing and Technologies: A Review. Open Journal of Animal Sciences, 10, 362-377.

https://doi.org/10.4236/ojas.2020.103022

Received: April 10, 2020

Accepted: June 8, 2020

Published: June 11, 2020

Copyright (c) 2020 by author(s) and Scientific Research Publishing Inc. This work is licensed under the Creative Commons Attribution International License (CC BY 4.0).

http://creativecommons.org/licenses/by/4.0/

\section{(c) (i) Open Access}

\begin{abstract}
Camel milk is unique because it is not easily processed into different dairy products that are common for cow milk. It lacks $\beta$-lactoglobulin and has low $\kappa$-casein that hinders processing of camel milk into different dairy products. Hence it needs different processing methods and technologies. To this effect attempts were made to manufacture dairy products such as feta cheese, soft brined cheese, and fermented milk from camel milk that had been produced at laboratory level. Camel milk powder has also been manufactures and marketed in Middle East and beyond. Currently there are remarkable progresses in camel dairy technologies that paved the way for production of different camel dairy products at small, medium and large scale. A number of experiments were conducted on camel milk processing technologies from preservation of camel milk using lactoperoxidase system activation using hydrogen peroxide $\left(\mathrm{H}_{2} \mathrm{O}_{2}\right)$ and thiocyanate as well as by $\mathrm{H}_{2} \mathrm{O}_{2}$ producing lactic acid bacteria (LAB) to metagenomic characterization of LAB isolated from spontaneously fermented camel milk. Therefore, this review paper is going to present current status of camel dairy technologies in Ethiopia.
\end{abstract}

\section{Keywords}

Camel Milk, Dairy Products, Dairy Technology

\section{Introduction}

Camel (Camelus dromedaries), the most climate resilient livestock, plays a significant role in the livelihood of pastoral and agro-pastoral communities in Ethiopia. Camel produces milk consistently despite frequent and severe drought and climate change. Camel milk is produced throughout the year and there is plenty of camel milk production during wet season, and this milk is mainly used 
for home consumption and the rest milk spoiled due to lack of access to market especially where there is no infrastructure for milk transportation and marketing.

With regard to processing of camel milk, it is similar to cow milk in terms of gross composition but differs in terms of its protein composition as it lacks $\beta$-lactoglobulin $(\beta$-Lg), has small amount of $\kappa$-casein $(\kappa$-CN) and larger amount of $\beta$-casein $(\beta-\mathrm{CN})$ in its casein micelles. The colloidal structure of camel milk is also different from that of cow milk with larger casein micelles and smaller fat globules. Therefore, it has been concluded that camel milk processing needs different processing methods and technologies than the conventional methods employed for cow milk processing.

Even though camel milk is difficult to process it into different dairy products, it has some unique chemical composition that makes it suitable for human nutrition, manufacturing of infant food and for functional foods. It is also reported that camel milk and milk products have health benefits such as antimicrobial effect, antidiabetogenic effects, inhibition of angiotensin converting enzyme and have antioxidant properties. Therefore, the objective of this review paper is to assess current technological advances in the area of camel dairy technology and future prospective to produce camel dairy products.

\section{Preservation of Raw Camel Milk}

Milk needs to be preserved from microbial multiplication and spoilage by cooling it within two hours after milking and using other preservation methods such as lactoperoxidase system where there is no electric power supply. Lactoperoxidase system (LPS) was tested for camel milk preservation [1] using hydrogen peroxide and thiocyanate, and found that chemical activation of LPS extended the shelf life of camel milk up to $12 \mathrm{hrs}$ at $30^{\circ} \mathrm{C}$. Moreover, LPS activation exhibited a bacteriostatic effect against coliform count (CC) and total bacterial count (TBC) and significantly $(\mathrm{P}<0.05)$ decreased the rate of growth of $S$. aureus and E. coli counts.

However, the use of chemicals such as LPS is not recommended due to food safety concern, and to avoid the use of chemical preservation of milk using LPS, six $\mathrm{H}_{2} \mathrm{O}_{2}$ producing strains of lactic acid bacteria (LAB) isolated from camel milk collected from Errer Valley, Eastern Ethiopia were evaluated for $\mathrm{H}_{2} \mathrm{O}_{2}$ excretion [2]. Theses LABs were Lactococcus lactis 22333, Weissella confusa 22308, W. confuse 22282, W. confusa 22296, S. infatarius 22279, S. lutetiensis 22319.The quantification of $\mathrm{H}_{2} \mathrm{O}_{2}$ by titration method showed W. confusa 22282 to produce significantly the highest amount $(302.10 \pm 20.55 \mathrm{mg} / \mathrm{L})$ of $\mathrm{H}_{2} \mathrm{O}_{2}$ in MRS broth. $W$. confusa 22282 was selected as best strain to activate the natural antimicrobial system in camel milk. The activation of LPs by $W$. confusa 22282 significantly reduced $(\mathrm{P}<0.05)$ the rate of lactic acid development and microbial growth (TBC and CC) in raw camel milk at ambient temperature $\left(18^{\circ} \mathrm{C}-24^{\circ} \mathrm{C}\right)$ and $E$. coli up to 18 hours of storage (Figure 1 and Figure 2). Therefore, production of 
Acidification Curves

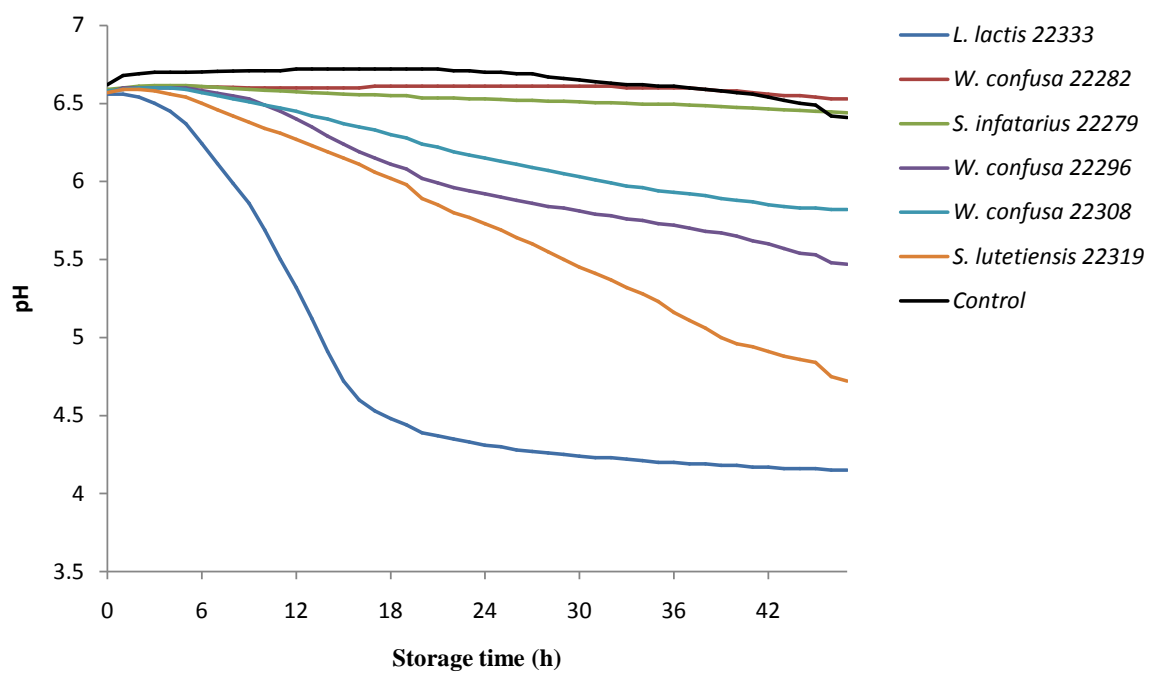

Figure 1. Acidification curves for $\mathrm{H}_{2} \mathrm{O}_{2}$ producing $\mathrm{LAB}$ strains in pasteurized camel milk $\left(21^{\circ} \mathrm{C}-23^{\circ} \mathrm{C}\right)[2]$.

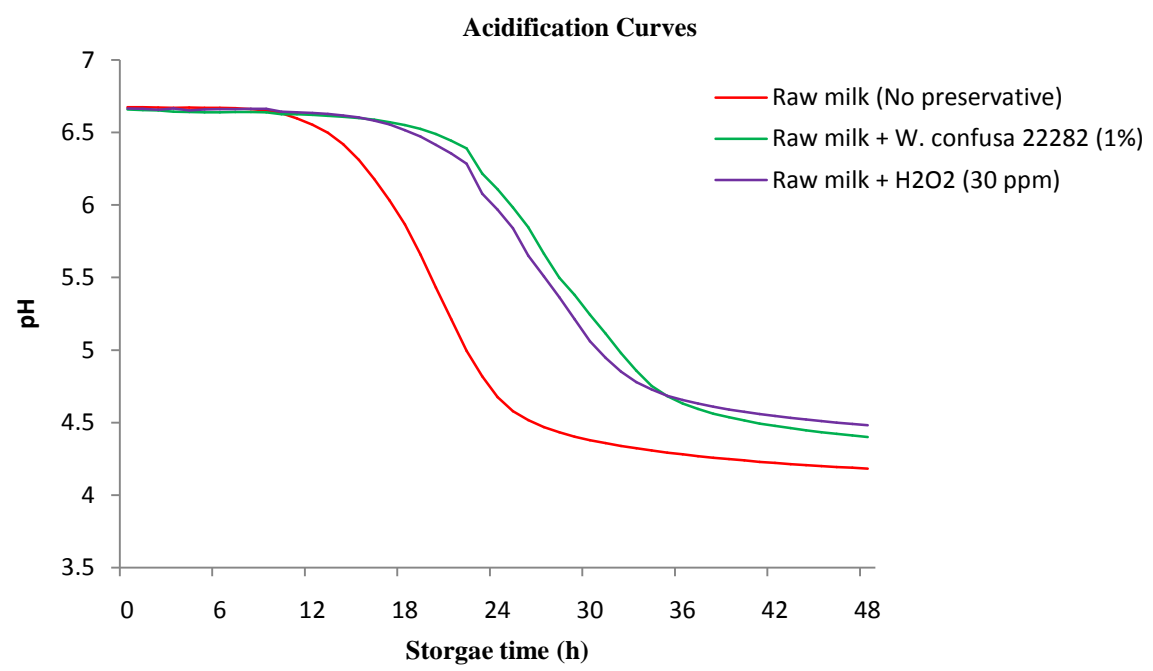

Figure 2. Acidification curves for $W$. confusa 22282 and $\mathrm{H}_{2} \mathrm{O}_{2}$ activated LPS and non-activated raw camel milk at room temperature [2].

$\mathrm{H}_{2} \mathrm{O}_{2}$ by $W$. confuse 22282 can activate the LPs and extend the storage stability of raw camel milk up to 18 hours at ambient temperature [2].

Provision of cooling facilities and utilization of renewable energy technologies such as solar energy for milk cooling and processing were identified as possible intervention strategies to enhance milk marketing from pastoral and agro-pastoral areas. Solar cooling system can be used to cool camel milk in rural settings where grid electric supply is unavailable, and the use of LPS and $\mathrm{H}_{2} \mathrm{O}_{2}$ producing $\mathrm{LAB}$ are not feasible. Hence, use of solar energy cooling system and cold chain could solve the limitation of camel milk marketing and spoilage. It can be used by organizing camel milk producers into camel dairy groups and/or cooperatives to establish market chain thereby to promote camel milk marketing. Solar milk 
cooling is effectively used in Kenya. The use of solar energy can reduce milk spoilage and thereby improve dairy farm productivity and income. Milk cooling and cold-chain storage can significantly decrease bacteria count and improves quality of milk supplied to market. These improvements found to play a significant role in the livelihoods of around one million smallholder dairy farming families in Kenya.

In Ethiopia access to electric power is around 57\%, and the number of households that are connected through the national electric power grid system are about 2.8 million [3]. But only $26.5 \%$ of the rural population have access to electricity and the majority of the population particularly in pastoral and agro-pastoral areas did not have access to electricity. According to the World Bank, Ethiopia ranked the second in the Sub-Saharan African countries having the highest energy generation capacity from hydropower, solar, wind, and geothermal energy resources. Solar energy is considered as the best option to reach the rural community in remote settings, particularly where there are high camel milk production potentials.

Moreover, mobile milk processing plant could be adopted for camel milk producing pastoral and agro-pastoral areas of the country. Mobile milk processing plants could be used where there is huge camel milk production but lack access to market due to distance from target market and lack of appropriate infrastructure. Mobile plant could produce different dairy products that are shelf stable and enable the producers to supply milk products to wider market destinations. It can be flexible to move from place to place depending on the mobility of camel herds. This plant can be integrated with solar energy milk cooling and processing facilities.

\section{Heat Treatment and Whey Proteins Composition}

The effect of heat treatment on whey protein composition was evaluated [4] and found that non-protein nitrogen of camel milk was not affected by heat treatment unlike that of cow milk. In cow milk non protein nitrogen content increased as heat treatment intensity increased. This could be attributed to the presence of degraded protein products as a result of heat treatments [5] [6] [7]. In camel and cow milk, the proportion of whey protein nitrogen significantly ( $\mathrm{P}$ $<0.05)$ decreased at $90^{\circ} \mathrm{C} / 5 \mathrm{~min}$ heat treatments and consequently, the total whey protein denaturation increased [4] (Table 1). The proportion of total whey protein denaturation significantly increased from $2.8 \%$ to $34 \%$ due to increased heat temperature from $72^{\circ} \mathrm{C}$ to $87^{\circ} \mathrm{C} / 26 \mathrm{sec}$ [8]. The proportion of whey protein denatured in camel milk found to be lower than that of cow milk which could be attributed to the relatively higher heat resistance of camel whey protein [7] [9].

\section{Effects of Heat Treatment on Individual Whey Proteins}

Identification of individual protein was also conducted using SDS-PAGE based on molecular weight and reported absence of $\beta$ - $\mathrm{Lg}$ in camel milk (lane $8-13$, Figure 3) [4]. Similarly, other authors [7] [10] [11] [12] [13] [14] reported that 
Table 1. Effect of heat treatment on total whey proteins of camel milk [4].

\begin{tabular}{|c|c|c|c|c|c|c|c|}
\hline \multirow{2}{*}{$\mathrm{mg} / 100 \mathrm{~g}$} & \multicolumn{6}{|c|}{ Heat treatments level $($ Mean $+\mathrm{SD})$} & \multirow{2}{*}{$P$ value } \\
\hline & Raw milk & $65^{\circ} \mathrm{C} / 30 \mathrm{~min}$ & $72^{\circ} \mathrm{C} / 30 \mathrm{sec}$ & $75^{\circ} \mathrm{C} / 5 \mathrm{~min}$ & $85^{\circ} \mathrm{C} / 5 \mathrm{~min}$ & $90^{\circ} \mathrm{C} / 5 \mathrm{~min}$ & \\
\hline $\mathrm{NCN}$ & $110.75 \pm 1.76^{\mathrm{a}}$ & $108 \pm 1.41^{\mathrm{a}}$ & $105.2 \pm 1.13^{\mathrm{a}}$ & $98.8 \pm 1.97^{\mathrm{b}}$ & $87.25 \pm 3.88^{c}$ & $74.00 \pm 2.82^{\mathrm{d}}$ & $* * *$ \\
\hline NPN & $29.75 \pm 0.70^{c}$ & $30.6 \pm 0.77^{\mathrm{bc}}$ & $31.6 \pm 2.26^{\mathrm{abc}}$ & $32.6 \pm 1.34^{\mathrm{abc}}$ & c $33.25 \pm 0.35^{\mathrm{ab}}$ & $33.90 \pm 0.14^{\mathrm{a}}$ & ns \\
\hline WPN & $81.00 \pm 1.41^{\mathrm{a}}$ & $77.5 \pm 2.12^{\mathrm{ab}}$ & $73.70 \pm 0.98^{\mathrm{b}}$ & $66.50 \pm 3.53^{c}$ & $54.00 \pm 4.24^{\mathrm{d}}$ & $40.10 \pm 2.68^{\mathrm{e}}$ & $* * *$ \\
\hline WPD\% & 0 & $4.30 \pm 0.98^{\text {ed }}$ & $9.00 \pm 2.82^{\mathrm{d}}$ & $18.0 \pm 0.2 .82^{\mathrm{c}}$ & ${ }^{c} 33.37 \pm 4.06^{\mathrm{b}}$ & $50.50 \pm 2.51^{\mathrm{a}}$ & $* * *$ \\
\hline
\end{tabular}

Mean value with same superscripts letter in the same row were not significantly different at $(\mathrm{P}<0.05)$; $\mathrm{NCN}=$ Non caseinnitrogen, $\mathrm{NPN}=$ Non protein nitrogen, $\mathrm{WPN}=$ whey protein nitrogen, $\mathrm{WPD} \%=$ whey protein denaturation $\%$, and $\mathrm{ns}=$ non-significant.

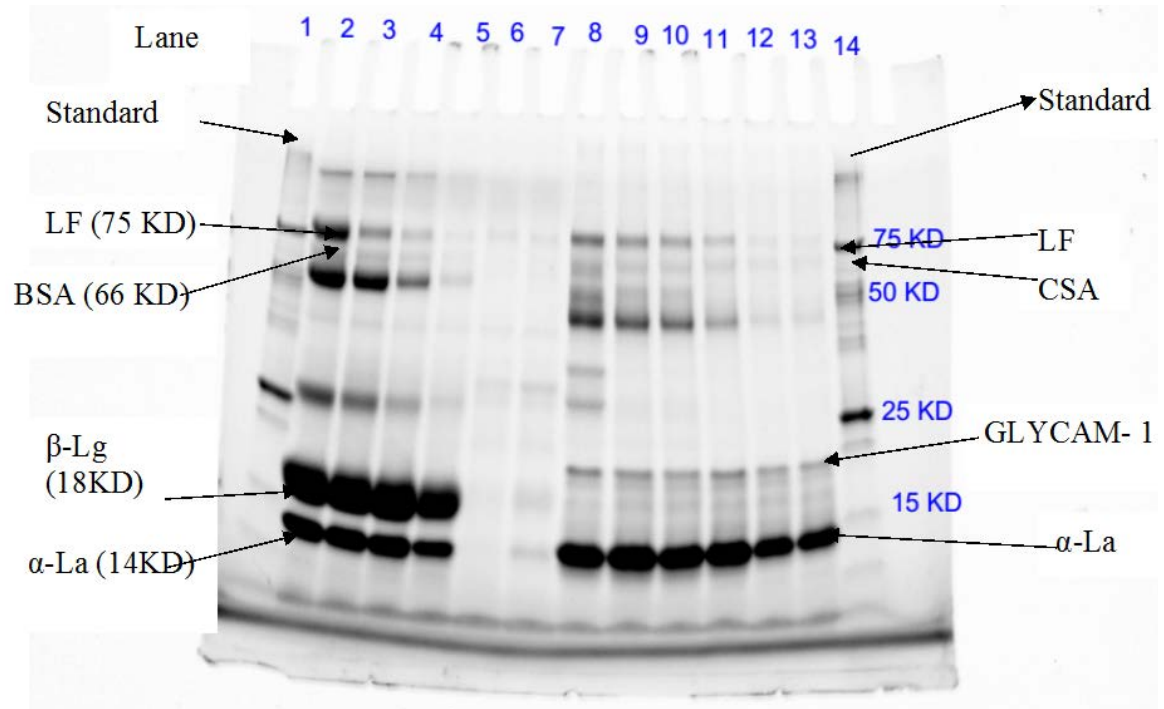

Figure 3. SDS-PAGE of whey proteins treated at various temperatures for camel and cow milk. Lane 2 to 7 for cow milk and Lane 8 to 13 for camel milk samples of Raw (reference sample), heated at $65^{\circ} \mathrm{C} / 30 \mathrm{~min}, 72^{\circ} \mathrm{C} / 30 \mathrm{sec}, 75^{\circ} \mathrm{C} / 5 \mathrm{~min}, 85^{\circ} \mathrm{C} / 5 \mathrm{~min}$ and $90^{\circ} \mathrm{C} / 5 \mathrm{~min}$, respectively. Lane 1 and 14 are protein standards [4].

camel milk is deficient in $\beta$-Lg. However, in cow milk $\beta$-Lg is the dominant whey protein [11] [14] [15] and denatures at temperatures above $75^{\circ} \mathrm{C}$.

Increase in heat treatment level did not affect the level of camel milk $\alpha$-La (Figure 3). But cow milk $\alpha$-La band intensity was significantly reduced with increasing heat treatment and totally vanished at temperature of $85^{\circ} \mathrm{C} / 5 \mathrm{~min}$ and $90^{\circ} \mathrm{C} / 5 \mathrm{~min}$. This is attributed to absence of $\beta$ - $\mathrm{Lg}$ in camel milk. In cow milk $\beta$ - $\mathrm{Lg}$ is known for its interaction with $\alpha$-La and enhances the interaction of $\alpha$-La with casein micelles because $\alpha$-La can form disulphide bonds but lacks the free thiol group of $\beta$-Lg, which commences and develops the interaction [16] [17].

The affiliation between denatured whey protein and casein micelles in camel milk needs to be examined in detail. Denatured $\alpha$-La and camel serum albumin (CSA) have the tendency to stick on hot surfaces of milk processing equipment either alone or along with $\kappa$-CN [18]. In camel milk, CSA might interact with $\mathrm{k}$-CN instead of $\alpha$-La owing to the non-denaturation of $\alpha$-La with increasing 
temperature. For raw milk adjusted to $40^{\circ} \mathrm{C}$, a short gelation time and high gel strength was obtained, and temperature of $65^{\circ} \mathrm{C} / 30 \mathrm{~min}$ and $72^{\circ} \mathrm{C} / 30 \mathrm{~s}$ heat treatment can be applied without affecting the rennetability of camel milk. But a more intensive heat treatment resulted in very low gel strength and there was no coagulation within $60 \mathrm{~min}$ [4]. Further research was recommended to elucidate the intricate interaction between camel milk proteins at different heat applications.

\section{Manufacturing of Cheese from Camel Milk}

Cheese is found to be a good method of preservation of perishable milk into more shelf stable dairy products. Nutritionally, it is well commendable for supplying the required nutrients to our body. The taste is also acceptable and endured in the community. But manufacturing of cheese from camel milk has been slowed down as a result of peculiar nature of camel milk; it lacks $\beta$-Lg, has low $\kappa$-CN, and has high percentage of $\beta$-CN. To overcome this obstacle a number of attempts were made whereby some of the attempts were successful and others were failed to produce acceptable cheese from camel milk [19].

In this regard, experiments were conducted to examine the impact of camel chymosin concentrations at 40,70 , and $100 \mathrm{IMCU} / \mathrm{L}$ on camel milk gelation properties and the effect of curd scalding at $55^{\circ} \mathrm{C}$ on the behaviour of soft un-ripened camel milk cheese [20]. The result of this experiment showed that the shortest gelation time was obtained for $100 \mathrm{IMCU} / \mathrm{L}$ and $70 \mathrm{IMCU} / \mathrm{L}$ camel chymosin concentration and maximum gel firmness was obtained for 40 IMCU/L camel chymosin concentration. The same authors concluded that use of $70 \mathrm{IMCU} / \mathrm{L}$ chymosin concentration and curd scalding can be used for soft unripened camel milk cheese manufacturing. Other researchers [21] investigated the effect of temperature, $\mathrm{pH}$, concentration of camel chymosin and addition of $\mathrm{CaCl}_{2}$ on $\mathrm{k}-\mathrm{CN}$ hydrolysis and kinetics of camel milk coagulation. They found higher $\mathrm{k}-\mathrm{CN}$ hydrolysis at $40^{\circ} \mathrm{C}, 55$ to $85 \mathrm{IMCU} / \mathrm{L}$ chymosin concentration and at $\mathrm{pH}$ of 6.0. Moreover, for gelation of camel milk to be initiated more than $95 \%$ $\mathrm{k}$-CN need to be hydrolysed and maximum hydrolysis of camel milk $\mathrm{k}-\mathrm{CN}$ can be achieved with increasing gelation temperature and camel chymosin concentration, and lower $\mathrm{pH}$. Therefore, camel milk casein gelation time can shorten by increasing gelation temperature and by addition of $\mathrm{CaCl}_{2}$ at a rate of $0.02 \% \mathrm{w} / \mathrm{w}$ [21].

\section{Cheese Making and Compositional Changes}

Production of cheese is a means of preserving valuable milk constituent [22] through a dehydration of coagulated milk using milk clotting enzymes [23] [24] and this process is reported to be difficult and tedious for camel milk [25] [26]. However, the advent of coagulant known as camel chymosin that has high specificity to $\kappa$-CN cleavage paved the way for success stories in camel milk cheese production. One of the success stories was manufacturing of soft brined cheese 
with camel chymosin and composition of this cheese exhibited differences in the first 20 days of ripening [27]. Salt in moisture (S/M) was increased with increase of $\mathrm{NaCl} \%(\mathrm{w} / \mathrm{w})$ and salting time (Table 2). There was degradation of some milk proteins and cheese made with $85 \mathrm{IMCU} / \mathrm{L}$ chymosin concentration showed a higher casein degradation. Degradation of $\beta-\mathrm{CN}$ in brined camel cheese was observed in later stage of ripening period while $\alpha \mathrm{S} 1-\mathrm{CN}$ was not degraded and remained intact [27].

Degradation of casein is a common phenomenon due to residual coagulant, enzyme from starter culture, nonstarter culture and milk enzymes like plasmin [23] [28]. The degraded soluble components of caseins diffuse to the brine during ripening [29] [30] [31]. The amount of total nitrogen in brined camel milk cheese was found to decrease during ripening period. Similarly, soluble nitrogen fraction decreased at ripening of soft brined cheese made from milk of other species as a result of migration of soluble components to brine [31] [32] [33]. Therefore, length of ripening period of cheese determines the biochemical changes in cheese [34] [35].

\section{Effect of Starter Cultures on Physicochemical Properties of Soft White Cheese}

The effect of starter cultures on the physicochemical properties, texture, and consumer preferences of soft white cheese (SWC) made from camel milk was investigated [36] (Table 3). The experiment employed five starter cultures; one thermophilic (STI-12), two blended (RST-743 and XPL-2), and two mesophilic (R-707 and CHN-22) cultures. Camel milk inoculated using STI-12 and RST-743 cultures resulted in faster acidification than XPL-2, R-707, and CHN-22 cultures. Camel milk soft white cheese (SWC) made using STI-12 and CHN-22 cultures gave lower $\mathrm{pH}$ (4.54) and titratable acidity (0.59), respectively, whereas R-707 culture resulted in high cheese yield $(13.44 \mathrm{~g} / 100 \mathrm{~g})$. Considering curd firmness, cheese yield, compositional quality, and textures, STI-12, RST-743, and R-707 cultures were found to be better for the manufacture of camel milk SWC [36].

Table 2. Physicochemical properties, salt in moisture and soluble nitrogen fraction of soft brined cheese made from camel milk during ripening (Means \pm SE) [27].

\begin{tabular}{cccccccc}
\hline Day & Cheese pH & Total solids (\%) & Ash (\%) & Fat (\%) & Protein (\%) & S/M of 2\% brine & S/M of 5\% brine \\
\hline 0 & $4.91 \pm 0.05^{\mathrm{a}}$ & $45.02 \pm 1.09^{\mathrm{a}}$ & $1.52 \pm 0.20^{\mathrm{b}}$ & $24.50 \pm 0.56^{\mathrm{a}}$ & $19.29 \pm 0.92^{\mathrm{a}}$ & $0.42 \pm 0.15^{\mathrm{c}}$ & $0.46 \pm 0.15^{\mathrm{c}}$ \\
20 & $4.49 \pm 0.05^{\mathrm{b}}$ & $39.83 \pm 1.09^{\mathrm{b}}$ & $3.09 \pm 0.20^{\mathrm{a}}$ & $21.94 \pm 0.56^{\mathrm{b}}$ & $17.81 \pm 0.84^{\mathrm{a}}$ & $0.25 \pm 0.15^{\mathrm{b}}$ & $6.67 \pm 0.15^{\mathrm{a}}$ \\
40 & $4.44 \pm 0.06^{\mathrm{b}}$ & $41.27 \pm 1.09^{\mathrm{ab}}$ & $3.22 \pm 0.20^{\mathrm{a}}$ & $22.19 \pm 0.56^{\mathrm{b}}$ & $15.53 \pm 0.84^{\mathrm{b}}$ & $0.74 \pm 0.15^{\mathrm{b}}$ & $6.68 \pm 0.15^{\mathrm{a}}$ \\
60 & $4.50 \pm 0.05^{\mathrm{b}}$ & $39.92 \pm 1.09^{\mathrm{b}}$ & $3.13 \pm 0.20^{\mathrm{a}}$ & $22.75 \pm 0.56^{\mathrm{b}}$ & $14.68 \pm 0.98^{\mathrm{b}}$ & $4.19 \pm 0.15^{\mathrm{b}}$ & $6.45 \pm 0.15^{\mathrm{a}}$ \\
\multicolumn{2}{c}{ Coagulant Level } & $\mathrm{pH} 4.4 \mathrm{SN}$ & TCA-SN & PTA-SN & & & \\
\multicolumn{2}{c}{$55 \mathrm{IMCU} / \mathrm{L}$} & $11.64 \pm 1.66^{\mathrm{b}}$ & $7.31 \pm 0.68^{\mathrm{b}}$ & $6.42 \pm 0.58^{\mathrm{b}}$ & & & \\
\multicolumn{2}{c}{ 85 IMCU/L } & $19.39 \pm 1.66^{\mathrm{a}}$ & $10.59 \pm 0.69^{\mathrm{a}}$ & $8.68 \pm 0.56^{\mathrm{a}}$ & & & \\
\hline
\end{tabular}

Means with the different superscript letter within a column are significantly different $(\mathrm{P}<0.05)$. Note: $\mathrm{pH} 4.4 \mathrm{SN}$, pH 4.4 soluble nitrogen; TCA-SN, trichloroacetic acid soluble nitrogen; PTA-SN, phosphotungstic acid soluble nitrogen; ICMU, international milk clotting units. 
Table 3. Physicochemical properties of soft cheese (Mean \pm SD) [36].

\begin{tabular}{|c|c|c|c|c|c|c|c|}
\hline Parameters & $\mathrm{pH}$ & Acidity (\%) & Yield $(\mathrm{kg} / 100 \mathrm{~kg})$ & Fat (\%) & Protein (\%) & TS (\%) & Ash (\%) \\
\hline \multicolumn{8}{|c|}{ Camel milk } \\
\hline STI-12 $\left(37^{\circ} \mathrm{C}\right)$ & $4.54 \pm 0.17^{\mathrm{c}}$ & $1.09 \pm 0.15^{\mathrm{a}}$ & $9.43 \pm 1.85^{b}$ & $18.71 \pm 0.56^{\mathrm{b}}$ & $16.29 \pm 0.11^{\mathrm{a}}$ & $40.40 \pm 0.46^{\mathrm{ab}}$ & $2.21 \pm 0.14^{\mathrm{ab}}$ \\
\hline $\mathrm{RST}-743\left(37^{\circ} \mathrm{C}\right)$ & $4.76 \pm 0.12^{\mathrm{bc}}$ & $0.87 \pm 0.02^{\mathrm{b}}$ & $9.77 \pm 0.98^{b}$ & $20.91 \pm 0.82^{\mathrm{a}}$ & $17.49 \pm 1.73^{\mathrm{a}}$ & $43.44 \pm 2.80^{\mathrm{a}}$ & $2.40 \pm 0.27^{\mathrm{a}}$ \\
\hline $\mathrm{R}-707\left(30^{\circ} \mathrm{C}\right)$ & $5.04 \pm 0.12^{\mathrm{ab}}$ & $0.71 \pm 0.07^{\mathrm{bc}}$ & $13.44 \pm 0.09^{\mathrm{a}}$ & $18.89 \pm 0.76^{\mathrm{b}}$ & $12.18 \pm 0.10^{\mathrm{b}}$ & $35.77 \pm 0.68^{c d}$ & $1.79 \pm 0.23^{b c}$ \\
\hline $\mathrm{XPL}-2\left(30^{\circ} \mathrm{C}\right)$ & $4.92 \pm 0.05^{\mathrm{ab}}$ & $0.73 \pm 0.08^{\mathrm{b}}$ & $10.18 \pm 0.27^{\mathrm{b}}$ & $17.99 \pm 0.45^{\mathrm{b}}$ & $16.33 \pm 0.55^{\mathrm{a}}$ & $38.54 \pm 0.7^{\mathrm{bc}}$ & $2.20 \pm 0.31^{\mathrm{ab}}$ \\
\hline $\mathrm{CHN}-22\left(30^{\circ} \mathrm{C}\right)$ & $5.20 \pm 0.06^{\mathrm{a}}$ & $0.59 \pm 0.02^{c}$ & $9.50 \pm 0.34^{\mathrm{b}}$ & $18.74 \pm 0.57^{\mathrm{b}}$ & $11.12 \pm 0.02^{\mathrm{b}}$ & $34.76 \pm 0.26^{\mathrm{d}}$ & $1.27 \pm 0.04^{\mathrm{c}}$ \\
\hline P-values & * & ** & * & * & ** & ** & * \\
\hline \multicolumn{8}{|c|}{ Cow milk } \\
\hline STI-12 $\left(37^{\circ} \mathrm{C}\right)$ & $4.62 \pm 0.01^{b c}$ & $0.95 \pm 0.01^{\mathrm{ab}}$ & $18.08 \pm 0.77^{\mathrm{a}}$ & $18.48 \pm 0.45^{\mathrm{a}}$ & $16.18 \pm 0.03^{\mathrm{a}}$ & $40.53 \pm 1.45^{\mathrm{a}}$ & $2.73 \pm 0.17^{\mathrm{a}}$ \\
\hline $\mathrm{R}-707\left(30^{\circ} \mathrm{C}\right)$ & $4.52 \pm 0.16^{\mathrm{c}}$ & $1.04 \pm 0.07^{\mathrm{a}}$ & $15.60 \pm 0.39^{c}$ & $18.02 \pm 0.77^{\mathrm{a}}$ & $15.63 \pm 0.14^{\mathrm{a}}$ & $38.87 \pm 0.49^{\mathrm{a}}$ & $2.22 \pm 0.14^{\mathrm{b}}$ \\
\hline $\mathrm{XPL}-2\left(30^{\circ} \mathrm{C}\right)$ & $4.64 \pm 0.03^{b c}$ & $0.96 \pm 0.01^{\mathrm{ab}}$ & $17.59 \pm 0.12^{\mathrm{ab}}$ & $16.4 \pm 0.36^{\mathrm{bc}}$ & $13.4 \pm 0.28^{b c}$ & $34.88 \pm 0.13^{\mathrm{b}}$ & $2.39 \pm 0.02^{b}$ \\
\hline $\mathrm{CHN}-22\left(30^{\circ} \mathrm{C}\right)$ & $4.95 \pm 0.04^{\mathrm{a}}$ & $0.74 \pm 0.02^{c}$ & $15.00 \pm 0.04^{\mathrm{c}}$ & $15.84 \pm 0.65^{\mathrm{c}}$ & $13.83 \pm 0.42^{\mathrm{b}}$ & $34.81 \pm 0.74^{\mathrm{b}}$ & $2.20 \pm 0.10^{\mathrm{b}}$ \\
\hline $\mathrm{P}$-values & * & * & $* *$ & * & $* * *$ & $* *$ & $* *$ \\
\hline
\end{tabular}

Means with different superscript letters within the same column are significantly different at $(\mathrm{P}<0.05)$; STI-12 = Streptococcus thermophilus, RST-743 = Lactococcus lactis subsp. lactis and Streptococcus thermophilus, R-707 = Lactococcus lactis subsp. lactis, Lactococcus lactis subsp. Cremoris; XPL-2 = Lactococcus lactis subsp. cremoris, Lactococcus lactis subsp. lactis, Lactococcus lactis subsp. lactis biovar diacetylactis, Leuconostoc species, and Streptococcus thermophilus, and CHN-22 = Lactococcus lactis subsp. cremoris, Leuconostoc pseudomesenteroides, Lactococcus lactis subsp. lactis biovar diacetylactis, Lactococcus lactis subsp. lactis, Leuconostoc mesenteroides.

Physicochemical properties were significantly different between SWC made from camel and cow milk in which $\mathrm{pH}$ of SWC made from camel milk using XPL-2 and CHN-22 cultures had significantly higher cheeses $\mathrm{pH}$ values than that of XPL-2 and CHN-22 cultures used for manufacturing of SWC from cow milk, respectively [36]. This vitiation attributed to the characteristics of milk types in which camel milk acidification takes longer time than cow milk [37]. Camel milk soft cheeses made by cultures RST-743 and CHN-22 had significantly higher fat than that of cow milk soft cheeses prepared using RST-743 and CHN-22 cultures [36].

\section{Camel and Cow Milk Cheeses Whey Compositions}

Whey can be used for food and pharmaceutical products. Whey contains functional food proteins, lactose, vitamins and minerals. Camel milk whey can be used to manufacture acidified drinks with better nutritive value in terms of essential amino acids, lactose, lactic acid, vitamins and minerals. Cheese whey composition in SWC made from camel milk resulted in fat composition of 1.12 \pm 0.09 when it was prepared using culture CHN-22 than STI-12, RST-743, R-707 and XPL- 2 cultures. Similarly, $1.10 \pm 0.26$ fat was found in brine-salted camel milk soft cheese whey [38] and $1.5 \%$ fat for camel milk cheese whey [39].

Camel milk soft cheeses whey composition made using cultures XPL-2 and CHN-22 was higher while lactose composition was higher for culture XPL-2 [36]. Similarly, $4.26 \pm 0.18$ lactose content of brine-salted soft camel cheese whey 
was reported [38]. Total solids and ash content were found to be higher for camel milk soft cheese whey prepared using cultures XPL-2 and CHN-22 than that of STI-12, RST-743 and R-707 cultures (Table 4).

\section{Starter Cultures and Texture of Camel Milk Soft Cheese}

Soft cheese made from camel milk using culture RST-743 found to be higher in resistance to fracture as compared to cheese prepared using cultures STI-12, R-707, XPL-2 and CHN-22 cultures (Figure 4). Soft cheeses prepared using RST-743 and STI-12 cultures contained lower moisture and higher protein, and

Table 4. Camel and cow milk cheeses whey compositions (g/100 g) [36].

\begin{tabular}{cccccc}
\hline Culture & Fat & Protein & Lactose & TS & Ash \\
\hline & & \multicolumn{2}{c}{ Camel milk cheese } \\
STI-12 & $0.57 \pm 0.01^{\mathrm{b}}$ & $0.65 \pm 0.05^{\mathrm{b}}$ & $3.88 \pm 0.09^{\mathrm{d}}$ & $6.74 \pm 0.13^{\mathrm{b}}$ & $1.39 \pm 0.09^{\mathrm{c}}$ \\
RST-743 & $0.34 \pm 0.02^{\mathrm{b}}$ & $0.66 \pm 0.02^{\mathrm{b}}$ & $4.39 \pm 0.02^{\mathrm{b}}$ & $6.58 \pm 0.01^{\mathrm{b}}$ & $1.18 \pm 0.03^{\mathrm{d}}$ \\
R-707 & $0.58 \pm 0.04^{\mathrm{b}}$ & $0.68 \pm 0.03^{\mathrm{b}}$ & $4.10 \pm 0.04^{\mathrm{c}}$ & $6.96 \pm 0.20^{\mathrm{b}}$ & $1.59 \pm 0.07^{\mathrm{b}}$ \\
XPL-2 & $0.57 \pm 0.37^{\mathrm{b}}$ & $0.80 \pm 0.04^{\mathrm{a}}$ & $4.95 \pm 0.02^{\mathrm{a}}$ & $7.46 \pm 0.31^{\mathrm{a}}$ & $1.13 \pm 0.04^{\mathrm{d}}$ \\
CHN-22 & $1.12 \pm 0.09^{\mathrm{a}}$ & $0.86 \pm 0.04^{\mathrm{a}}$ & $4.08 \pm 0.09^{\mathrm{c}}$ & $7.90 \pm 0.16^{\mathrm{a}}$ & $1.83 \pm 0.10^{\mathrm{a}}$ \\
P-values & $* * *$ & $*$ & $* * *$ & $*$ & $* * *$ \\
& & Cow milk cheese & & \\
STI-12 & $0.22 \pm 0.01^{\mathrm{ab}}$ & $0.90 \pm 0.02^{\mathrm{a}}$ & $4.84 \pm 0.08^{\mathrm{b}}$ & $6.79 \pm 0.07^{\mathrm{bc}}$ & $0.82 \pm 0.01^{\mathrm{ab}}$ \\
RST-743 & $0.16 \pm 0.02^{\mathrm{bc}}$ & $0.94 \pm 0.04^{\mathrm{a}}$ & $5.01 \pm 0.15^{\mathrm{b}}$ & $6.90 \pm 0.03^{\mathrm{ab}}$ & $0.79 \pm 0.11^{\mathrm{b}}$ \\
R-707 & $0.13 \pm 0.02^{\mathrm{c}}$ & $0.99 \pm 0.13^{\mathrm{a}}$ & $4.89 \pm 0.03^{\mathrm{b}}$ & $6.60 \pm 0.21^{\mathrm{c}}$ & $0.58 \pm 0.01^{\mathrm{c}}$ \\
XPL-2 & $0.26 \pm 0.03^{\mathrm{a}}$ & $0.67 \pm 0.01^{\mathrm{b}}$ & $5.28 \pm 0.01^{\mathrm{a}}$ & $7.15 \pm 0.04^{\mathrm{a}}$ & $0.93 \pm 0.01^{\mathrm{a}}$ \\
CHN-22 & $0.15 \pm 0.04^{\mathrm{bc}}$ & $0.87 \pm 0.01^{\mathrm{a}}$ & $5.25 \pm 0.03^{\mathrm{a}}$ & $6.89 \pm 0.05^{\mathrm{ab}}$ & $0.61 \pm 00^{\mathrm{c}}$ \\
P-values & $*$ & $*$ & $*$ & $*$ & $* *$ \\
\hline
\end{tabular}

Means with different superscript letters within the same column showed significant differences $(\mathrm{P}<0.05)$.

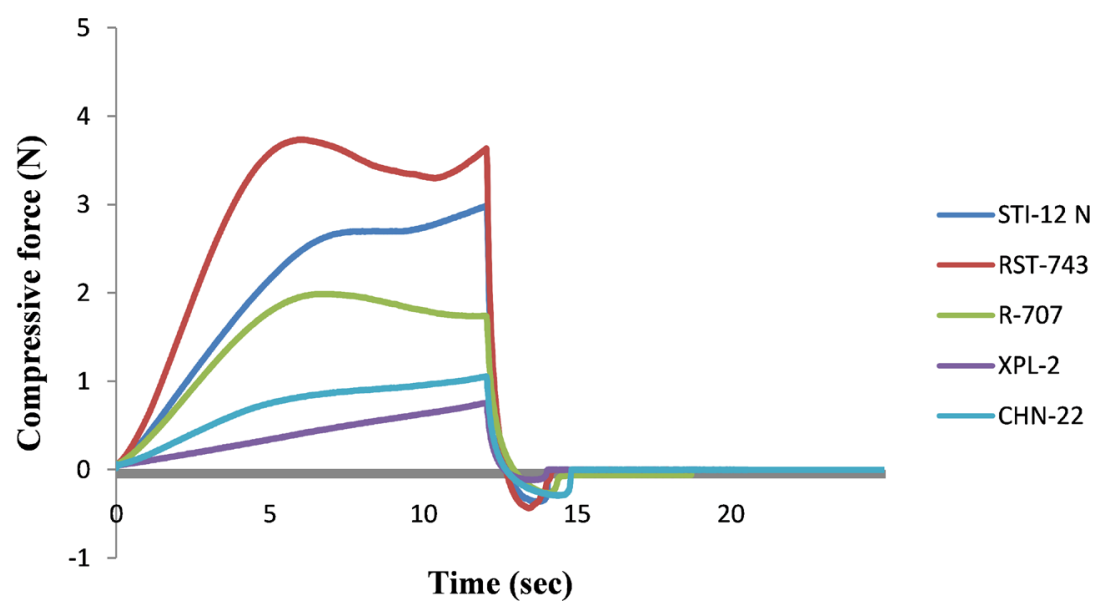

Figure 4. Compression curves of cheeses made from camel milk using five different cultures [36]. 
showed higher resistance to fracture as compared to cheese prepared using the other cultures [36].

Camel milk soft cheese sample made with XPL-2 culture showed similar moisture value with STI-12 culture and protein value with RST-743 and STI-12 cultures; however, since XPL-2 undergo syneresis it might be less resistance to fracture. The difference in textures could be due to moisture and protein contents of the cheese samples [36]. Therefore, it is most plausible to conclude that rheological characteristics of cheeses can be affected by level of cheese moisture and protein contents [40].

Instrumental analysis of rheological textures of firmness, brittleness and stickiness using micro-stable texture analyser revealed difference in firmness among camel milk cheeses produced using different cultures. The reported result indicated that camel milk soft cheese produced with RST-743 culture resulted in higher firmness and brittleness than camel soft milk cheese prepared using XPL-2 and CHN-22 cultures [36]. These variations could be attributed to alteration of the effect of $\mathrm{pH}$ on texture due to the level of moisture and calcium contents of cheese. Moisture content of cheese determines the level of swelling of casein sub-micelles with the increase in casein-to-moisture ratio. As a result small variation in moisture content can bring significant change on fresh cow milk cheese texture [41]. Even though increased fat content resulted in smoother and softer cheese [42], higher fat and water content inclines to weaken the protein structure [43]. On other hand increased casein and fat content produce firmer cheese [42].

\section{Consumer Preference}

Evaluation of consumer preference for camel milk soft cheese manufactured using combination of different cultures were conducted and found that XPL-2 culture had lower scores for appearance and overall acceptance than that made using the other cultures discussed earlier [36]. On the other hand, camel milk soft cheeses made using XPL-2 and CHN-22 cultures had higher aroma and taste. These variations in flavor could be attributed to the inherent properties of an aromatic forming cultures inoculated in the milk during cheese-making.

On the other hands camel milk soft cheese prepared using R-707 scored lower firmness than cheese prepared using the other cultures; however, STI-12 and RST-743 had resulted in similar firmness. In addition to camel milk soft cheese made with culture R-707, camel milk cheeses made using STI-12 and RST-743 scored higher crumbliness than cheese prepared using XPL-2 and CHN-22 cultures [36]. The variations in consumer preference could be due to the natural property of starter cultures in the course of acidification and curd development in which $\mathrm{CO}_{2}$, diacetyl and acetaldehyde synthesized and contributed to the development of different textural and flavor properties of the cheeses [44].

\section{Fermented Camel Milk}

Fermented milk drinks are as acceptable as manufacturing of camel milk chees- 
es. A number of attempts were conducted to manufacture fermented camel milk. It was found that fermented camel has poor viscosity and consistence. To characterize microbial communities in spontaneously fermented camel milk, metagenomic 16S rRNA sequencing was conducted and lactic acid bacteria were isolated with the aim to select strains that can be used as starter cultures for camel milk fermentation. In this experiment, the authors found that fermented camel milk was dominated by Lactobacillales and Enterobacteriaceae. Lactococcus lactis, Lactobacillus plantarum, and Pediococcusaci dilactici were strains of species isolated from fermented camel milk with potential use as starter cultures. Moreover, species of Lc. lactis, P. acidilactici, and Streptococcus infantarius are fast acidifiers of camel milk. Potentially pathogenic gram-negative microorganisms were found to be common in spontaneously fermented camel milk [45].

\section{Ultrahigh Temperature and Sterilized Camel Milk}

Production of pasteurized camel milk has been successfully undertaken and applied industrially for mass production. But ultrahigh temperature (UHT) and sterilization of camel milk resulted in protein instability. Hence, research has been conducted to solve this problem. Currently Camelicious-Emirates industry for camel milk is producing UHT camel milk and marketing worldwide. It has a shelf life of 12 months if it is stored in cool and dry places. In Ethiopia, one dairy plant in Fafum town of Ethiopian Somali Region plans to manufacture UHT camel milk (personal communication).

Previously production of UHT camel milk had been investigated [46] and to this end different chemicals such as sodium hydroxide $(\mathrm{NaOH})$, calcium chloride $\left(\mathrm{CaCl}_{2}\right)$, $\mathrm{k}-\mathrm{CN}$ from cow, sodium dihydrogen phosphate anhydrous, disodium hydrogen orthophosphate and Ethylenediaminetetraacetic acid disodium (EDTA) salt were used to stabilize camel milk proteins in UHT milk. It was found that $\mathrm{k}-\mathrm{CN}$ and calcium content are the main factors that affect heat stability of camel milk protein. It was proposed that increasing $\mathrm{pH}$ could be helpful for camel milk protein heat stability. Addition of phosphate could be used in commercial scale to improve heat stability of whole camel milk.

\section{Conclusion}

Currently satisfactory progresses have been made in camel dairy technology that enable to process camel milk into different dairy products which in turn will have positive impact on the livelihood of camel rearing communities. It was found that a pasteurization temperature not exceeding $72^{\circ} \mathrm{C} / 30 \mathrm{sec}$ should be adopted for cheese making from camel milk. The difference in speed of acidification in cow and camel milk is found to be due to difference in proteolysis rather than the previous assumption due to the presence of antimicrobial substance in camel milk. Concerning starter cultures utilization in camel milk fermentation, R-707 is preferred mesophilic culture and STI-12 as preferred thermophilic culture for camel milk fermentation. Production of UHT camel milk is 
feasible and being manufactured by some dairy plants in Middle East but it needs development of precise procedure and protocols. Currently there are about five dairy plants in Ethiopia that are dedicated to process camel milk into different dairy products and need to be supported by the scientific community and funding organizations.

\section{The Ways Forward}

Camel milk is marketed in raw state and there is a serious problem of lack of cold chain. The safety and microbial quality of camel milk is also of substandard and does not meet standards set by Quality Standards Authority of Ethiopian. Moreover, most of the camel milk is not marketed in pastoral and agro-pastoral areas of the country. To overcome these problems introduction of cold chain in the form of solar milk cooling will play paramount importance. Hence concerned organizations or institutions should step up and take immediate action of introduction of cold chain by identifying potential camel milk production areas. Moreover, quality and quantity camel milk production need to be promoted through introduction of improved and affordable milking equipment such as mazzi milk cans. The other strategies that could solve and reduce camel milk spoilage is use of mobile milk pasteurization facilities that can easily be transported and planted in remote areas. This could be augmented by solar energy generation for power supply that could be used both for mobile pasteurization and milk cooling refrigerators. Alternatively, wind energy and other renewable energy source could be developed and used where feasible to exploit such energy sources. Mobile dairy plant suitable and flexible to pastoral and agro-pastoral settings could also be introduced for sustainable development of the sector. Mobile plants can be run by solar energy and supply pasteurized camel milk and other dairy products to the targeted markets. Tailor made trainings and awareness creation should be done on quality and quantity milk production, preservation, processing, and marketing of camel milk. Promotion of camel milk and dairy products consumption should be made through mass media, school milk day and other relevant means. Establishment of dairy cooperatives have indispensable role for development of camel dairy sector and hence deserves to get priority and protection from the government. Without dairy cooperatives it will be very difficult to bring the desired development and promotion of camel dairy in particular and dairy in general.

\section{Conflicts of Interest}

The authors declare no conflicts of interest regarding the publication of this paper.

\section{References}

[1] Bekele, A., Mitiku, E., Yonas, H. and Egon, B.H. (2017) Activation of Lactoperoxidase System: Evaluation of the Acidification Rate, Microbial Quality, \& Shelf Life of Camel and Cow Milk. East African Journal of Sciences, 11, 107-116. 
[2] Dakalo, D. (2018) Preservation of Raw Camel Milk by Lactoperoxidase System Using Hydrogen Peroxide Producing Lactic Acid Bacteria. M.Sc. Thesis, Haramaya University, Bate.

[3] Africannews (2017) Ethiopia Reports Huge Revenue in Power Supply over Last 10 Months.

https://www.africanews.com/2017/05/19/ethiopia-reports-huge-revenue-in-power-s upply-over-last-10-months

[4] Almaz, G., Egon, B.H., Mitiku, E., Yonas, H. and Richard, I. (2019) Effect of Heat Treatment on Denaturation of Whey Protein and Resultant Rennetability of Camel Milk. LWT-Food Science and Technology, 101, 404-409.

https://doi.org/10.1016/j.lwt.2018.11.047

[5] Kappeler, S., Farah, Z. and Puhan, Z. (1998) Sequence Analysis of Camelus dromedarius Milk Caseins. Journal of Dairy Research, 65, 209-222.

https://doi.org/10.1017/S0022029997002847

[6] El-Agamy, E.I., Nawar, M., Shamsia, S.M., Awad, S. and Haenlein, G.F.W. (2009) Are Camel Milk Proteins Convenient to the Nutrition of Cow Milk Allergic Children? Small Ruminant Research, 82, 1-6.

https://doi.org/10.1016/j.smallrumres.2008.12.016

[7] Felfoul, I., Beaucher, E., Cauty, C., Hamadi, A., Gaucheron, F. and Ayadi, M.A. (2016) Deposit Generation during Camel and Cow Milk Heating: Microstructure and Chemical Composition. Food and Bioprocess Technology, 9, 1268-1275. https://doi.org/10.1007/s11947-016-1714-1

[8] Rynne, M.N., Tom, B., Alan, K. and Tim, P.G. (2004) Effect of Milk Pasteurization Temperature and in Situ Whey Protein Denaturation on the Composition, Texture and Heat-Induced Functionality of Half-Fat Cheddar Cheese. International Dairy Journal, 14, 989-1001. https://doi.org/10.1016/j.idairyj.2004.03.010

[9] El-Agamy, E.L. (2000) Effect of Heat Treatment on Camel Milk Proteins with Respect to Antimicrobial Factors: A Comparison with Cow's and Buffalo Milk Proteins. Food Chemistry, 68, 227-232. https://doi.org/10.1016/S0308-8146(99)00199-5

[10] Kappeler, S., Farah, Z. and Puhan, Z. (2003) 5'-Flanking Regions of Camel Milk Genes Are Highly Similar to Homologue Regions of Other Species and Can Be Divided into Two Distinct Groups. Journal of Dairy Science, 86, 498-508. https://doi.org/10.3168/jds.S0022-0302(03)73628-5

[11] Hinz, K., O’Connor, P.M., Huppertz, T., Ross, R.P. and Kelly, A.L. (2012) Comparison of the Principal Proteins in Bovine, Caprine, Buffalo, Equine and Camel Milk. Journal of Dairy Research, 79, 185-191. https://doi.org/10.1017/S0022029912000015

[12] Saliha, S.A., Dalila, A., Chahra, S., Saliha, B. and Abderrahmane, M. (2013) Separation and Characterization of Major Milk Proteins from Algerian Dromedary (Camelus dromedarius). Emirates Journal of Food and Agriculture, 25, 283-290. https://doi.org/10.9755/ejfa.v25i4.15496

[13] El Haj, A.E. and Freigoun, S. (2015) Camel's Milk Protein Fractionation by SDS-Poly-Acrylamide Gel Electrophoresis. International Journal for Agro-Veterinary and Medical Sciences, 9, 41-45.

[14] Omar, A., Harbourne, N. and Oruna-Concha, M.J. (2016) Quantification of Major Camel Milk Proteins by Capillary Electrophoresis. International Dairy Journal, 58, 31-35. https://doi.org/10.1016/j.idairyj.2016.01.015

[15] Farah, Z. (1993) Composition and Characteristics of Camel Milk. Journal of Dairy Research, 60, 603-626. https://doi.org/10.1017/S0022029900027953

[16] Singh, H. and Waungana, A. (2001) Influence of Heat Treatment of Milk on Cheese 
Making Properties. International Dairy Journal, 11, 543-551. https://doi.org/10.1016/S0958-6946(01)00085-1

[17] Donato, L. and Guyomarch, F. (2009) Formation and Properties of the Whey Protein/ $\kappa$-Casein Complexes in Heated Skim Milk: A Review. Dairy Science and Technology, 89, 3-29. https://doi.org/10.1051/dst:2008033

[18] Felfoul, I., Lopez, C., Gaucheron, F., Attia, H. and Ayadi, M.A. (2015) Fouling Behaviour of Camel and Cow Milks under Different Heat Treatments. Food and Bioprocess Technology, 8, 1771-1778. https://doi.org/10.1007/s11947-015-1529-5

[19] Yonas, H., Egon, B.H., Eyassu, S., Mitiku, E., Richard, I. and Stefan, K. (2016) Functional and Technological Properties of Camel Milk Proteins: A Review. Journal of Dairy Research, 83, 422-429. https://doi.org/10.1017/S0022029916000686

[20] Tekuam, W., Mohammed, Y.K., Richard, I., Yonas, H. and Mitiku, E. (2017) Coagulation and Preparation of Soft Unripened Cheese from Camel Milk Using Camel Chymosin. East African Journal of Sciences, 11, 99-106.

[21] Adda, J., Gripon, J.C. and Vassal, L. (1982) The Chemistry of Flavour and Texture Generation in Cheese. Food Chemistry, 9, 115-129.

https://doi.org/10.1016/0308-8146(82)90073-5

[22] Yonas, H., Egon, B.H., Eyassu, S., Mitiku, E. and Richard, I. (2016) Factors Influencing the Gelation and Rennetability of Camel Milk Using Camel Chymosin. International Dairy Journal, 60, 62-69. https://doi.org/10.1016/j.idairyj.2016.01.013

[23] Fox, P.F. and McSweeney, P.L.H. (1998) Heat-Induced Changes in Milk. In: Fox, P.F. and McSweeney, P.L.H., Eds., Dairy Chemistry and Biochemistry, Blackie Academic and Professional, London, 347-378.

[24] Brighenti, M., Govindasamy-Lucey, S., Lim, K., Nelson, K. and Lucey, J.A. (2008) Characterization of the Rheological, Textural, and Sensory Properties of Samples of Commercial US Cream Cheese with Different Fat Contents. Journal of Dairy Science, 91, 4501-4517. https://doi.org/10.3168/jds.2008-1322

[25] Bornaz, S., Sahli, A., Attalah, A. and Attia, H. (2009) Physicochemical Characteristics and Renneting Properties of Camels' Milk: A Comparison with Goats', Ewes' and Cows' Milks. International Journal of Dairy Technology, 62, 505-513. https://doi.org/10.1111/j.1471-0307.2009.00535.x

[26] Ramet, J.P. (2001) The Technology of Making Cheese from Camel Milk (Camelus dromedarius) (No. 113). Food and Agriculture Organization, Rome.

[27] Yonas, H., Egon, B.H., Eyassu, S., Mitiku, E., Mikael, A.P., Rene Lametsch, F.R. and Richard, I. (2018) Rheological and Sensory Properties and Aroma Compounds Formed during Ripening of Soft Brined Cheese Made from Camel Milk. International Dairy Journal, 81, 122-130. https://doi.org/10.1016/j.idairyj.2018.01.007

[28] Sousa, M.J., Ardo, Y. and Mcsweeney, P.L.H. (2001) Advances in the Study of Proteolysis during Cheese Ripening. International Dairy Journal, 11, 327-345. https://doi.org/10.1016/S0958-6946(01)00062-0

[29] Guinee, T.P. (2004) Salting and the Role of Salt in Cheese. International Journal of Dairy Technology, 57, 99-109. https://doi.org/10.1111/j.1471-0307.2004.00145.x

[30] Guinee, T.P. and Fox, P.F. (2004) Salt in Cheese: Physical, Chemical and Biological Aspects. In: Fox, P.F., McSweeney, P.L.H., Cogan, T.M. and Guinee, T.P., Eds., Cheese: Chemistry, Physics and Microbiology, 3rd Edition, Vol. 1, Elsevier Academic Press, London, 207-261. https://doi.org/10.1016/S1874-558X(04)80069-1

[31] Anifantakis, E.M. (1996) Traditional Feta Cheese. In: Robinson, R.K. and Tamime, A.Y., Eds., Feta and Related Cheeses, Wood Head Publishing Limited, Cambridge, 
49. https://doi.org/10.1533/9781845698225.49

[32] Hayaloglu, A.A., Guven, M. and Fox, P.F. (2002) Microbiological, Biochemical and Technological Properties of Turkish White Cheese "Beyaz Peynir". International Dairy Journal, 12, 635-648. https://doi.org/10.1016/S0958-6946(02)00055-9

[33] Michaelidou, A.M., Alichanidis, E., Polychroniadou, A. and Zerfiridis, G. (2005) Migration of Water-Soluble Nitrogenous Compounds of Feta Cheese from the Cheese Blocks into the Brine. International Dairy Journal, 15, 663-668. https://doi.org/10.1016/j.idairyj.2004.09.013

[34] Pappas, C.P., Kondyli, E., Voutsinas, L.P. and Mallatou, H. (1996) Effects of Salting Method and Storage Time on Composition and Quality of Feta Cheese. Journal of the Society of Dairy Technology, 49, 113-118. https://doi.org/10.1111/j.1471-0307.1996.tb02502.x

[35] Tesfemariam, B., Eyassu, S., Richard, I., Mohamed, Y.K. and Egon, B.H. (2017) Processing Challenges and Opportunities of Camel Dairy Products: A Review Article. International Journal of Food Science, 2017, Article ID: 9061757. https://doi.org/10.1155/2017/9061757

[36] Birhanu, B., Egon, B.H., Mitiku, E., Richard, I. and Yonas, H. (2019) Effect of Starter Cultures on Properties of Soft White Cheese Made from Camel (Camelus dromedarius) Milk. Journal of Dairy Science, 102, 1108-1115. https://doi.org/10.3168/jds.2018-15084

[37] Omar, A., Al haj, Hamad, A. and Al Kanhal (2010) Compositional, Technological and Nutritional Aspects of Dromedary Camel Milk. International Dairy Journal, 20, 811-821. https://doi.org/10.1016/j.idairyj.2010.04.003

[38] Konuspayeva, G., Camier, B., Aleilawi, N., Al-Shumeimyri, M., Al-Hammad, K., Algruin, K., Alshammari, F., Beaucher, E. and Faye, B. (2016) Manufacture of Dryand Brine-Salted Soft Camel Cheeses for the Camel Dairy Industry. International Journal of Dairy Technology, 70, 92-101. https://doi.org/10.1111/1471-0307.12319

[39] Shahein, M.R., Hassanein, A.M. and Zayan, A.F. (2014) Evaluation of Soft Cheese Manufactured from Camel Milk and Buffalo Milk. World Journal of Dairy and Food Sciences, 9, 213-219.

[40] Bongiolo, R., Schwinden, E., Fritzen-Freire, C.B., Penteaodo, M., Silvio, A. and Daguuer, H. (2014) Rheological, Physicochemical and Authenticity Assessment of Minas Frescal Cheese. Food Control, 45, 22-28. https://doi.org/10.1016/j.foodcont.2014.04.012

[41] Gunasekaran, S. and Ak, M.M. (2003) Cheese Rheology and Texture. CRC, Boca Raton. https://doi.org/10.1201/9781420031942

[42] Guinee, T.P., Feeney, E.P. and Fox, P.F. (2001) Effect of Ripening Temperature on Low Moisture Mozzarella Cheese. Texture and Functionality, 81, 475-485. https://doi.org/10.1051/lait:2001146

[43] Fox, P.F., Guinee, T.P., Cogan, T.M. and McSweeney, P.L.H. (2017) Cheese: Structure, Rheology and Texture. In: Fox, P.F., Guinee, T.P., Cogan, T.M. and McSweeney, P.L.H., Eds., Fundamentals of Cheese Science, Springer, Boston, 475-532. https://doi.org/10.1007/978-1-4899-7681-9

[44] Walstra, P., Wouters, J.T.M. and Geurts, T.J. (2006) Dairy Science and Technology. 2nd Edition, Taylor and Francis Group, CRC Press, Boca Raton.

[45] Angelina, F., Tesfemariam, B., Anil, K., Shazad, H., Martin, F.L., Martin, I.B., Yonas, H., Kim, I.S., Mitiku, E., Richard, I. and Egon, B.H. (2017) Characterisation of Lactic Acid Bacteria in Spontaneously Fermented Camel Milk and Selection of Strains for Fermentation of Camel Milk. International Dairy Journal, 73, 19-24. 
https://doi.org/10.1016/j.idairyj.2017.04.007

[46] Omar, A., Alhaj, A., Metwalli, A.M. and Elsayed, A. (2011) Heat Stability of Camel Milk Proteins after Sterilisation Process. Journal of Camel Practice and Research, 18, 277-282. 